\title{
Using Indigenous Knowledge in Agro-Forestry Practices: a Strategy for Livelihood Sustainability, in the Mount Oku Region of Cameroon
}

\author{
Jicenta N. Foncha (Phd) ${ }^{1 *}$, Asongwe, G. Azinwie (Phd) ${ }^{1}$, Che E. Fuh (Msc) ${ }^{2}$ \\ ${ }^{1}$ Department of Development Studies, Pan African Institute for Development-West Africa (PAID-WA) Buea, P.O. Box \\ 133 Buea, South West Region Cameroon \\ ${ }^{2}$ Department of Forestry, Faculty of Agronomy and Agricultural Sciences, University of Dschang, Cameroon
}

How to cite this paper: Foncha, J. N., Asongwe, G. A., Fuh, C. E. (2019) Using Indigenous Knowledge in Agro-Forestry Practices: a Strategy for Livelihood Sustainability, in the Mount Oku Region of Cameroon. International Journal of Food Science and Agriculture, 3(4), 299-307.

DOI: $10.26855 /$ ijfsa.2019.12.006

*Corresponding author: Jicenta N. Foncha (Phd), Department of Development Studies, Pan African Institute for Development-West Africa (PAID-WA) Buea, P.O. Box 133 Buea, South West Region Cameroon.

Email: Jacinta_foncha@yahoo.com

Tel: 237675201496

\begin{abstract}
Forests provide adjacent communities with livelihood opportunities; during periods of uncertainty, shocks and stress, indigenous knowledge is used for alternate livelihoods. This study focused on the use of indigenous knowledge by local communities in the creation of agro-forestry alternatives amidst conservation programs in the Mount Oku Forest, North West Region, Cameroon. Based on frontline and secondary villages, three communities were randomly selected from the three tribes (Nso, Kom, and Oku) that make up the forest region. Selected Participatory Rural Appraisal tools were used to collect relevant data. Resources extracted from the forest were ranked; trees extracted from forest and planted in farms were identified, farm produce before and after the practice of agro-forestry was assessed. The paired sample t-test was used to test differences between agricultural productions from farms and livelihood opportunities before and after agro-forestry practices. The results indicated that there was a positive and significant difference $(p<0.05)$ in agricultural production and livelihood opportunities, viz-a-viz forest cover. Though there was diversification in livelihood opportunities, the lack of incorporation of basic scientific approaches of agro-forestry was a major limitation. There is need for a blend of indigenous and scientific knowledge and training of farmers, in the practicing of agro-forestry practices for forest sustenance and livelihood assurance in the Mt Oku area.
\end{abstract}

\section{Keywords}

Forest, indigenous knowledge, agro-forestry, Livelihoods improvements

\section{Introduction}

Forests provide adjacent communities with livelihood opportunities and act as 'safety - nets' during periods of uncertainty, shocks and stress. Traditionally, people in Sub Sahara Africa, have for long managed their resources and associated landscape by using their indigenous knowledge to sustain their livelihoods and cultures. This knowledge has been transmitted through generations and is embodied in the people's languages, cultures, values, beliefs, rituals, community laws and governance systems. One aspect of this knowledge base has been the planting of indigenous trees in home farms not only to serve as boundaries among compounds, but to provide shelter from scorching heat during the dry season, maintain soil moisture, and provide fuel, fodder and food to mention but these. This can be referred to as, the use of indigenous knowledge to reduce pressure on forests. The practice of simultaneously cultivating crops alongside trees, both of which provided food, timber, firewood, fodder, medicinal plants, green manure, honey amongst others as well as ecosystem services, was traditionally known as compound farms or home gardens and has been around for a long time (Ndenecho, 2005, Eze and Ndenecho, 2006). 
The Food and Agriculture Organization of the United Nations, FAO,(2010); World Bank, (2014), predicted that, by 2050 food production will have to increase by over 60 percent to meet the increasing global demand for food as the world's population swells to 9.3 billion. The FAO further recognizes agro-forestry farming using trees, as one of the means to help meet the rising demand for food and fuel. As noted by the FAO, (2010), Trees outside Forest (ToF), encompasses integrated tree-based farming systems in farm lands and pasture lands to promote sustainable agricultural production and the conservation forest resources. The FAO, (2001), further notes that, ToF, is beneficial to small scale farmers as it bridges the gap between food production and environmental protection, as it facilitates the restoration of ecosystem services and improves fertility. This is supported by the findings from El - Lakany, (2004), who emphasized, that there is a strong synergy between people and forest; people depend on forest and the sustainable development of the forest relies on people.

As noted by Foncha, (2012), fallen plant leaves (trees) decay thereby adding nutrients to the soil and maintaining moisture for a longtime. Meanwhile, the presence of trees in farms acts as wind breaks and also shades the soil from direct sunlight thus reducing evaporation. Foncha's, (2012) is reechoed by Agrawal,(2002), Negash and Achalu, (2008) who noted that, agroforestry systems have potentials of providing ecosystem services similar to natural forests, as they store carbon dioxide and improve micro climates through the retention of moisture and improvement of soil fertility as leaves fall and decomposes. According to Jose, (2009), trees not only provide habitats for creatures such as birds, insects and fungi, (which facilitate pollination) but make available shelter from winds, animals and humans. Thus agroforestry provides all the benefits derived from forests.

The co- existence between farms and forests has been noted by Torres, (1985), which he describe as agroforestry, the deliberate combination of trees with crop plantation or pasture, or both in an effort to optimize the use of excessive resources to satisfy the objectives of producers in a sustainable manner. In a related work, Rao and Mack Dicken, (1991), have noted that agroforestry is land use that involves deliberate retention, introduction or mixture of trees, and other woody perennial crop and animal production fields with resultant benefits from the ecological and economic interaction. Similarly, Lungdrean and Raintreey, (1983) and Sinhai,(1985), have outlined some characteristics of agroforestry as involving two or more species of plants, comprising at least one which is woody perennial and animals either a spatial mixture or temporal sequence and further reported that, within a cycle of more than one year two or more output/ harvest result. As noted by Torres, (1985) and World Agro Forestry Center, (2008), agro forestry systems, have ecological and economical interactions involving different components with more productive, sustainable and diversified output from the land than with the conventional mono-cropping or mixed cropping systems. According to ICRAF, (2007), agroforestry is a collective name for all land use systems and practices in which wood perennials are deliberately grown on the same land management units as crops, trees and animals. It can be in some form of spatial arrangement or in a time sequence, with ecological and economic interactions between wood and non-wood components.

For long, indigenous people have used their knowledge in intensively managing agricultural land, as their large families (mostly polygamous) depend on their limited land coupled with short fallow periods for livelihood opportunities (sufficient production of food crop variety throughout the year, self-employment and increase in household income, and access to market among others) and other opportunities to improve agronomic practices (nutrient and water management) and environmental services. Indigenous agricultural and biological resource management became an integral part of culture and the history of local communities, as it not only offers opportunities for sustainable resource management, but supports socio-ecological and socio-economic benefits. Thus, the indigenous knowledge on agroforestry needs to be further strengthened through research and development on modern practices Deb et. al. (2009). This will systematically develop integrated land use systems and practices where positive interaction between trees and crops are encouraged and maximized, thereby reversing environmental degradation and achieving the Sustainable Development Goals.

Recently, increasing population, has led to increasing land use activities and pressure on land and this has created land scarcity. The absence of fallow (soil to regain its fertility) coupled with inappropriate farming methods (slash and burn), has also led to the deterioration of farm yields, consequently, affecting the livelihood of farmers as it becomes difficult to generate the income needed to cater for household needs. Farmers tend to be forced to turn to the forest to look for new farmlands and to exploit other forest resources. As stated by ICRAF, (2009) this has led to shortage of biomass for energy supply, increasing agricultural activities in the forest to meet increasing demand for food accelerated land and environmental degradation resulting from deforestation. This is what initiated the more towards multiple land use systems to enable the production of agricultural crops, tree production and livestock on the same unit of land outside the forest. It was also intended to reduce pressure on scarce farmland, by replacing the less efficient traditional systems of farming which accelerated degradation. In Kenya the initial interest in agroforestry was a strategy and potential 
innovation to ensure that the agricultural resources base and biophysical environment are not degraded, as to impede the attainment of the Sustainable Development Goals. The more in Kenya was also to meet up with the shortage in energy (biomass), and scarcity of agricultural land as well as satisfy the increasing demand for food for the rapidly increasing population. As reiterated by Quandt et. al. (2017), the development of agroforestry in Kenya was in two phases: firstly, the traditional, using indigenous knowledge and secondly, the scientific agroforestry development. In Kashmir valley, traditional agroforestry is multifunctional as it supports substantial ecosystem services, livelihoods and acts as carbon sink, playing a vital role in climate change adaptation Islam et al. (2017).

This scenario is akin to what obtains in the Mount Oku Forest Region in the North West Region of Cameroon. The Mt Oku forest is an important biodiversity hot spot in Cameroon with a high level of endemism. As noted by Thomas et al. (2001), and Asanga (2002), the unsustainable exploitation of forest resources for livelihood sustenance as a result of shortage in farming land, led to the unprecedented degradation of the forest, which before the institution of the forest conservation program had been reduced to 20,000 hectares of its original size. Faced with this challenge the Government of Cameroon was left with no other option but to carry out a conservation program from 1987 to 1995, when the adjacent community was completely sent out of the forest (Gardner et al. 2001). In the midst of this uncertainty, shocks and stress, the farmers sustainably removed the valued trees from the forest and planted either in their farms or compounds (thus going back to the traditional compound farm practices) as a coping strategy for livelihood sustainability amidst the conservation program. The population in the Mount Oku Region are so tied to their tradition, and only people in traditional sacred councils were tasked to harvest some species of trees. In fact, it is taboo to plant 'sacred' trees used for rituals in the farms (thus indigenous method of specie conservation). Since villages are grouped to form (Forest Management Institutions) FMIs, members of traditional sacred councils in the various FMIs sustainably removed the species associated with sacred tradition. Agroforestry in the Mount Oku region, has had a long tradition where trees are integrated in crops and livestock production systems according to agro- climatic and other prevailing conditions. Varieties of traditional crops, rhizomatous crops, vegetables, fruits and other trees in their traditional systems which are valuable for farmers' everyday life are continuously cultivated to meet the goals of income generation, effective risk management, and combatting household food insecurity.

This work is predicated on the use of indigenous knowledge by local communities in the creation of agro forestry; as a coping strategy for livelihood sustenance, in the Mount Oku Forest Region, North West Region Cameroon. The work a.) Identifies and ranks resources extracted from the forest, based on their importance to the communities b.) Singles out trees extracted from the forest and planted on farms c.) Assesses farm produce before and after the practice of agroforestry and d.) Examines income and livelihood opportunities before and after the practice of agroforestry.

\section{Materials and Methods}

\subsection{Description of the study area}

Mount Oku forest in the Northwest Region of Cameroon is located between longitude $10^{\circ} 20^{\prime} \mathrm{E}$ and $10^{\circ} 35^{\prime} \mathrm{E}$ and latitude $6^{\circ} 07^{\prime} \mathrm{N}$ and $6^{\circ} 17^{\prime} \mathrm{N}$ (figure 1). The forest area is made up of the Kilum Mountain range and the Ijim Ridge forests. Located $3011 \mathrm{~m}$ above sea level, it covers 20,000 ha (Asanga, 2002). The mountain is part of the Western Highlands of Cameroon, commonly referred to as the Bamenda Highland. The summit of the mountain is very cold and clouded, with mean maximum temperature ranging between $16.5-19^{\circ} \mathrm{C}$ and mean minimum temperature between $19-10.5^{\circ} \mathrm{C}$, while the rainfall varies from 2850 to $3050 \mathrm{~mm}$ yearly. The area experiences two seasons: rainy and dry seasons. The rainy season runs from May to September and the dry season between October and April Neba, (1982), and Numbem, (1985). Due to the prevalence of mist and cloud, the humidity is high (about 90percent) and the incidence of sunshine low (Macleod, 1986).

According to Furon, (1963), Mount Oku is geologically formed from volcanic rocks (Tertiary basalt and Trachyte lava), though some uplifting of older granite and gneiss basement rocks has also occurred (Neba, 1982;

The soils therefore vary greatly. They are strongly influenced by the parent materials, altitude, topography and human activities.

\subsection{Sampling Techniques}

The study started with a reconnaissance survey to get background information of the study area. During this survey three Fondoms (Nso, Oku, and Kom) that make up the Mount Oku Forest Region were visited. This was followed by a transect walk, with the aid of two field assistants who were familiar with the study area. The different stakeholders such 
as the Forest Management Institutions (FMI), Forest Users Groups (FUG), Traditional Authorities (TA) and Extension Workers were identified and contacted. Using purposive sampling, FMIs were chosen based on frontline villages. The Participatory Rural Appraisal tool (PRA) was used in collecting data. The instruments used included: questionnaires, Semi-structured Interview (SSI), group discussions and a transect walk. The attendance registers of the various FMIs were also consulted, while the list of trees with scientific and local names including their functions was used to facilitate the identification of trees. A total of 150 farmers were chosen (50 per FMI) with an average size ranging from $500 \mathrm{~m}^{2}$ to $1000 \mathrm{~m}^{2}$ or 1 ha. 2.3

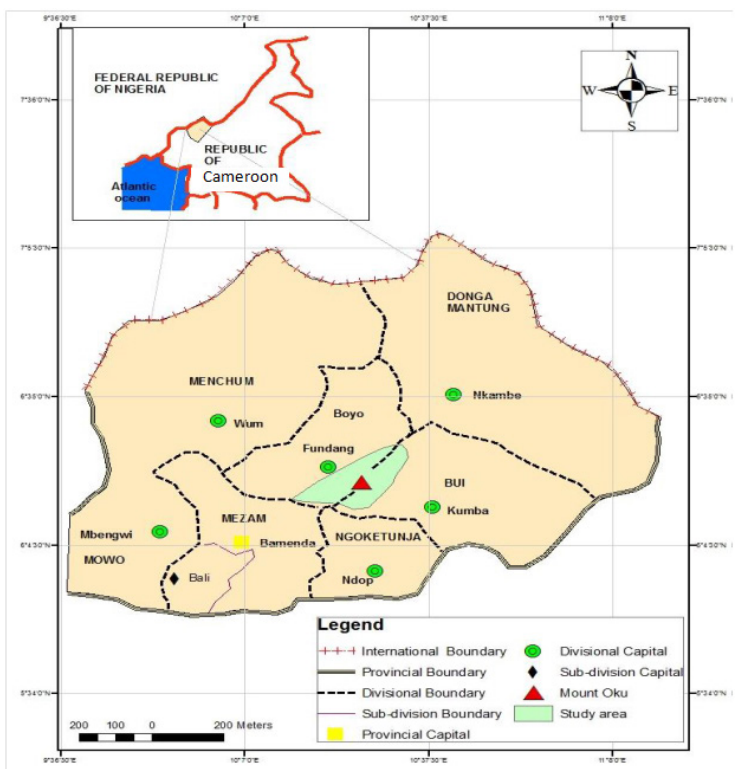

Figure 1. Map of the North West Region of Cameroon showing the Mount Oku Forest Source: Asanga, (2001).

\subsection{Data Analyses}

Apart from the institutional analyses and development framework, the data were also subjected to descriptive and inferential statistics (regressions, and correlations) to test hypotheses using the SPSS package version 17.5.

\section{Results and Discussions}

\section{1. identification and ranking of trees extracted from the forest based on their importance to the community}

The indigenous communities around the Mount Oku area have in the past carried out a variety of activities to pursue their livelihoods. Unfortunately, these activities facilitated the degradation of the forest. In response to the need for farmland, agroforestry was introduced where valuable plants/ trees were sustainably removed from the forest and planted in farms (Table 1).

\begin{tabular}{|c|c|c|c|c|c|c|c|c|}
\hline $\mathbf{s} / \mathbf{n}$ & Uses & No. of Species & Upper Shinga & Bikov & Mutef & Total & Ranking & Trees Planted in farms \\
\hline 1 & Fuel wood & 4 & 20 & 18 & 35 & 77 & 4 & ------ \\
\hline 2 & Medicinal Plants & 30 & 48 & 42 & 30 & 150 & 1 & Planted \\
\hline 3 & Wood Carving & 9 & 23 & 28 & 15 & 75 & 6 & Planted \\
\hline 4 & Timber for construction & 4 & 24 & 28 & 21 & 77 & 4 & Planted \\
\hline 5 & Musical Instrument & 2 & 10 & 12 & 8 & 32 & 8 & Planted \\
\hline 6 & Farm Tools & - & 41 & 42 & 25 & 108 & 2 & ------ \\
\hline 7 & Food & - & 35 & 41 & 20 & 96 & 3 & Planted \\
\hline 8 & Insecticide & 1 & 3 & 5 & 0 & 9 & 9 & Planted \\
\hline 9 & Rituals/Tradition & 6 & - & - & - & 6 & 11 & ------ \\
\hline 10 & Dye & 1 & 3 & 5 & 0 & 9 & 9 & ------ \\
\hline 11 & Fencing & 5 & 21 & 27 & 15 & 68 & 7 & Planted \\
\hline
\end{tabular}


The trees used by the communities were identified and ranked as follows: medicinal plants $>$ farm tools $>$ foods $>$ fuel wood and timber for construction $>$ wood carving $>$ fencing $>$ musical instruments $>$ dye and insecticide $>$ rituals and tradition. The population apparently had good knowledge of ethno botanical plants used for healing. They also have a long time tradition and belief in traditional medicine handed down to them by their ancestors. Thirty species of plants were identified as being used for traditional medicine. In all medicinal plants ranked first. The mount Oku Region is known all over Cameroon as the center for traditional medicine Foncha (2012). People for instance, travel over Cameroon to Oku for traditional healing especially those with complicated illnesses like, diabetes, madness, urinary and nerve disorder, bone fracture, abdominal pains, fever and fungi. Despite the hospitals and integrated health centers opened by the government and private clinics, most people still prefer traditional medicine due to its accessibility and affordability and also the perception of the people who believe so much in traditional treatment (Prabhat et al. 2017). Farm tool was ranked second, although no particular plant specie was identified as being use. Most often, it was gotten from other trees that were felled for other uses, such as wood carving and logging. However this region is rural and subsistence agriculture is the predominant occupation and the inability to get modern farm tools due to poverty, is evident reason why farmers have no option but to turn to the forest for farming tools. Food was ranked third. Forests are known to act as safety- nets for most rural communities as they collect, gather or harvest food for their sustenance. Most of the food are NTFP, (berries, leaves, roots, fungi, fruits). The collection process itself does not degrade the forest, but the foot paths created in the process lead to forest fragmentation. Fuel wood and Timber were ranked fourth. Fuel wood is the main source of domestic energy (for cooking), and it is used by all households: Even those with kerosene and cooking gas still use fuel wood. Besides the households, wood is used by restaurant operators and local brewery producers in their operations. Fuel wood collection is usually done by women as they carry out their farming activities or children who collect dry branches of fallen wood. Mutef one of the communities, ranked highest in fuel wood collection because of its accessibility to urban centers and the heterogeneous nature of the community. Most youth without farmland were inclined to engage in fuel wood collection in the forest to sustain their livelihoods. Four species were identified for timber extraction. Traditionally, mud bricks are used as building material and the timber is used for roofing. However, the eucalyptus, an exotic species, (does not take long to mature as indigenous species) is widely used for roofing and are planted in home gardens. The branches are used for fuel wood and farm tools. Wood carving is a major activity in the region as well and it was ranked sixth with nine species being used. The region is noted for carving and sculpture, which attracts a lot of tourists, and most of the products are found in handicraft shops/ centers and airports thus playing an important role in the value chain; it creates employment most of which is family-oriented (men do the carving while women and girls polish and decorate the products). Fencing was a long time tradition practiced in the home / compound gardens and which served as wind breaks, boundaries and sources of fodder supply. Most families are equally involved in small scale animal rearing (goats and sheep) that does not require the services of shepherds. These animals are either tied around the fences or their fodder is cut and taken to the stalls as noted by Ndenecho, (2007). The extraction of trees for musical instruments were also identified and ranked eighth. This activity is strongly associated with culture and ancestral beliefs usually attached to sacred societies or groups. Insecticide and dye were not major activities. They were predominant in home / compound farms. Except for the insecticide species that are being extracted and planted in farms, the dye has been replaced by kola nuts which has multi- functions (stimulant, dye), generates employment and attracts high income. Although six species of insecticide were identified with rituals and tradition, these species were not extracted as they were found mostly in sacred grooves and required special people and special periods for harvesting. It was also considered a taboo for those species to be planted out of the forest. Before the institution of agroforestry kola nuts were planted in compound farms as it is a multipurpose trees and widely planted in all the farms. Medicinal plants comprise trees and shrubs which regulates soil erosion and, maintain soil moisture and shelter. In all, other trees planted for wood carving, timber for construction, musical instruments, insecticide and dye performed similar functions like: stabilizing the soil, serve as wind breaks, and facilitating the decomposition of leaves which add to soil nutrient and maintain soil moisture, and provide fuel wood and farm tools. Trees for fencing acted as wind break and provide fodder for animals (goats and sheep). Other indigenous trees that provide food (wild berries) and fruits were also planted in the farms. Multi Storey fruit trees were also planted on the farms, which formed an essential part for nutrition and dietary needs. Most of these trees are bee-loving species, thus enabling bee farming, an income generation activity. These trees are planted on farms with food crops like rhizome- cocoyam, yams; maize, cassava, beans, soya beans, plantain, sugar- cane all having different benefits that issue from inter-cropping.

\subsection{Trees extracted from the forest and planted in the farms}

During group discussions it was noted that not all the farmers practiced agroforestry. The table below presents data on farmers who practiced agroforestry or did not practice. (Table 2) 


\begin{tabular}{clccc}
\hline $\mathrm{s} / \mathrm{n}$ & Communities & No. of farmers & Number practice of agroforestry & \% of agroforestry farmers \\
\hline 1 & Upper Shinga & 50 & 42 & 84 \\
2 & Bikov & 50 & 35 & 70 \\
3 & Mutef & 50 & 8 & 16 \\
& Total & 150 & 85 & 170 \\
\hline
\end{tabular}

From the table above, it is evident that, Bikov is a frontline FMI, not very accessible and the population is predominantly agrarian, thus, more people are engaged in the practice of agroforestry. With no access to the forest, the population has resorted to the planting of useful trees/crops on their farms and compounds as handed to them by their ancestors. Upper Shinga is more accessible although it is a frontline village where agricultural activities are also predominant. This accessibility has attracted secondary and tertiary activities, and as such the population is not as engaged in agriculture/ agroforestry as those in Bikov. Mutef is a secondary village, which is accessible and has a heterogeneous population (including civil servants) and characterized by secondary and tertiary activities. Agriculture is mostly practiced by indigenes and most of them food stuff comes from Bikov.

On the other hand farmers who are not engaged in the practice of agroforestry advanced the following challenges: the customary land tenure system (which it is mostly hereditary) where women are not (household heads/ widows) entitled to inheritance in families where there are males. The landless who hire land were allowed to plant only food and perennial crops, not trees which is considered long term investments. Poverty is another reason for not practicing agroforestry; the refusal to access the forest means seedlings from nurseries have to be bought and, most of these farmers who are women, widows (vulnerable and marginalized) do not have the financial resources or social capital to procure seedlings.

\subsection{Assessment of farm produce before and after agroforestry practice}

Before and after the institution of agroforestry.

Table 3. Shows the output of crops and fruit trees before and after Agroforestry farming, per year.

\begin{tabular}{|c|c|c|c|c|c|c|c|c|c|}
\hline \multirow{2}{*}{ Crops / Trees } & \multicolumn{3}{|c|}{ Before Agroforestry yearly } & \multicolumn{3}{|c|}{ After Agroforestry yearly } & \multirow[b]{2}{*}{$\begin{array}{l}\text { Quantity } \\
\text { change }\end{array}$} & \multirow[b]{2}{*}{$\begin{array}{l}\text { income } \\
\text { change }\end{array}$} & \multirow[b]{2}{*}{$\%$ change } \\
\hline & Quantity & $\begin{array}{c}\text { Unit Price } \\
\text { FCFA }\end{array}$ & Total & Quantity & $\begin{array}{l}\text { unit price } \\
\text { FCFA }\end{array}$ & Total & & & \\
\hline Corn & 8 BKTS & 18000 & 144000 & 30 BKTS & 18000 & 540000 & 22 & 396000 & 73.33 \\
\hline Beans & 4 BKTS & 20000 & 80000 & 25 BKTS & 20000 & 500000 & 21 & 420000 & 84.00 \\
\hline Groundnuts & 10 BKTS & 25000 & 250000 & 30 BKTS & 25000 & 750000 & 20 & 500000 & 66.67 \\
\hline Cassava & $2 \mathrm{BGS}$ & 20000 & 40000 & $10 \mathrm{BGS}$ & 20000 & 200000 & 8 & 160000 & 80.00 \\
\hline Yams & $5 \mathrm{BGS}$ & 18000 & 90000 & $12 \mathrm{BGS}$ & 18000 & 216000 & 7 & 126000 & 58.33 \\
\hline Cocoyam & $3 \mathrm{BGS}$ & 15000 & 45000 & $10 \mathrm{BGS}$ & 15000 & 150000 & 7 & 105000 & 70.00 \\
\hline Sugar Cane & ---- & ---- & --- & $6 \mathrm{BDLS}$ & 2000 & 12000 & 7 & 35000 & 46.67 \\
\hline Plums & ---- & ---- & ---- & 10 BKTS & 12000 & 120,000 & 13 & 26000 & 39.39 \\
\hline Pears/Avocado & ---- & ---- & ---- & 7 BKTS & 4500 & 31500 & 2 & 40000 & 40 \\
\hline Oranges & ---- & ---- & ---- & 12 BKTS & 5000 & 60000 & 0 & 0 & 0 \\
\hline Honey & ---- & ---- & ---- & 40 LTRS & 3500 & 140000 & 0 & 0 & 0 \\
\hline Kola Nuts & ---- & ---- & ---- & 8 BKTS & 15000 & 120000 & & & \\
\hline
\end{tabular}

Amongst the crops cultivated, were: maize/corn, beans, groundnuts, rice, cassava, cocoyam and yams which are not only staple food crops (for consumption) but are sold in urban centers within and out of the region. Maize is the main staple food crop not only in the North West Region of Cameroon but all over the country. It is transformed into various forms by the different ethnic groups for consumption. Maize is used by brewery industries and also by the local communities for the production / brewery of local beers popularly called "Shah, and Quasha". Maize is also used in producing animal and poultry feed, reason why the demand is high. Beans and soya beans are major sources of protein and have high 
nutritive values, and are eaten all over Cameroon and even exported to neighboring Central African countries. After harvesting, the residue are used to prepare animal food, or left to add nutrients to the soil. Soya beans is known to have high nutritive value as it is used in preparing milk, and custard for babies. Groundnut equally has a high nutritive value and is used as a food complement (soup). Sometimes it is transformed into cooking oil, or eaten as snacks, or converted to pudding which is sold in markets or along the highways by road side vendors. Groundnuts like beans are being eaten and sold all over the country and exported to neighboring countries. Cassava is not highly consumed in its primary state but is transformed into 'Garri' (tapioca) and sold in and out of Cameroon. It can also be transformed to "water-fufu and boboloh" indigenous meals that are eaten all over Cameroon. Cocoyam and yams are biennial crops mostly sold to outsiders, as the consumption rate by the local population is low.

Increase agricultural productivity is attributed to farmers using their indigenous knowledge in spacing for light to stimulate the maximum growth of plants through pruning and cutting down trees that have reached maximum utilization stage. This provides fuelwood and forage to the local communities Owonubi, (2002). Wood ash and animal dung (from goats) are used as local insecticide for pest management. The indigenous people around the Mount Oku region, have a long tradition of planting sweet potatoes and pumpkins in their farms and these have three measure functions: food for animals like guinea pigs and rabbits (mostly the leaves) and as cover crops to protect the soil from erosion and the maintenance of soil moisture. This is often integrated in to their new farming systems. The planting of a mixture of trees, food crops and animal rearing (specifically goats) has led to ecological stability and improved the socio economic wellbeing of the farmers.

Besides the ecological advantages provided by the trees planted in the farms, farmers have realized an increase in income (see table 2) and witnessed an improvement in their dietary intake as most trees yield fruits of high value (and which are either sold or consumed). Kola nuts are also widely planted in all the farms and compound farms and are consumed widely and also considered a commercial products (exported). They are and as alternatives for dyeing as well.

\subsection{Livelihood diversification Strategies}

The introduction, and practice of as well as proceeds from agroforestry have led to the diversification of livelihood strategies as shown on figure 2 below.

Livelihood options before and after the institution of agroforestry in the Mount Oku Region

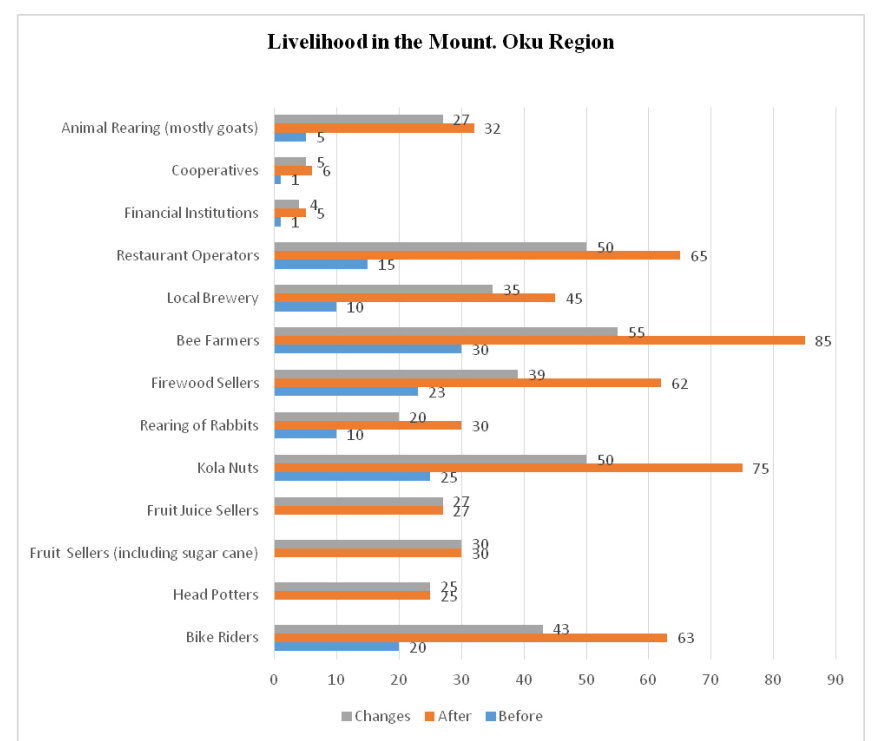

A major activity in the area resulting from agroforestry is bee farming. The cultivation of varieties of trees (mostly fruits / flowerings plants) is what has attracted bees to the Mount Oku region. In all the farms that were studied, all the farmers practice bee farming and interestingly, it did not involve the destructive traditional methods where fire was involved. Besides honey production, local wine, medicine (cough syrup), cosmetics and locally made home candles were also produced and the income from these activities are used to augment the living standards and livelihoods of the people. The variety of byproducts from honey has also created employment to the population (through transforming and selling of the products). Kola nut which is largely produced is a cash crop which is not only exported but sold locally in 
drinking parlors (as it acts as stimulant). It is also used in the dyeing of fabric (it use has led to capacity building and the empowerment of most women).

Restaurant operators also witnessed an increase, given the increase in the variety of crops produced. Increase in agricultural activities invariably attracted biker rider to facilitate the transportation of farm produce to homes and markets. Fire wood is the major source of domestic energy in restaurants. Simplicity of use and affordability in relation to domestic cooking gas and kerosene stove coupled with the reduction in conflicts with conservationist, as it was evident that the agroforestry program made provision for fire wood are factors that led to an increase in the sale of firewood and to an in increase household incomes. Increase in corn production and difficulty in storage led to its transformation to "Shah and Corn Beer". This was facilitated by the absence of any cost incurred in the buying of the corn as it is from their farms. Before the institution of agroforestry, farm produce were easily transported by family members/ farmers. With a boost in farm yields came an increase in head porters especially for farmers who do not have enough money for bikes: Most of these head porters do transportation from homes to the markets on weekly village market days. As shown in Fig 3 after the institution of agroforestry fruit trees were integrated in to farms; this led to increases in fruit production and the challenges of post-harvest storage of fruits led to their transformation into fruit juice which are sold in schools, restaurants and road sides by vendors. Animal rearing was mostly sedentary in nature and not destructive. Goats are simply tied around hedges which are used as fences in farms or compounds while some are kept in stalls and fodder taken to them. Guinea pigs and rabbits feed mainly on sweet potatoes and pumpkin leaves harvested from farms. Guinea pigs and rabbits provide the population with protein as they are cheaper than chicken or meat. This explains their high demand. The increase in agricultural productivity led to economic exchange, employment, increase in household incomes, increase in financial institutions and cooperatives to help facilitate access to agricultural input, market outlets and boost resilience to shocks and stress in the face of changing climate, land scarcity and food insecurity.

\section{Conclusion}

A majority of Indigenous Peoples' social organization, cultural survival and identity are rooted in their ancestral lands. For long traditional agroforestry has been practiced to preserve these identity as most often the trees integrated in the farms are of great significance to the people. This indigenous knowledge in the practice of agroforestry, also acts as a bridge between food production and environmental protection. However, little or no attention is usually paid to traditional agroforestry because of lack of documentation and validation. Increase in population and multiple land use systems has led to shortage of fallow periods and farm land. This has impaired the livelihoods of most rural communities which depends on farming. There is need for all stake holders to create institutional mechanisms and provide supportive structures that will integrate traditional and modern agroforestry systems. This will entail the provision of environmentally sound technology, the creation of investment incentives and the institution of efficient market mechanisms. The successful implementation of all these would combat poverty, enhance rural development and mitigate the impact of climate change.

\section{References}

Agrawal, A. (2002). Indigenous knowledge and the politics of classification. International Social Science Journal 54 (173), $287-297$.

Asanga, C. (2002). Community forest management at the Kilum-Ijim mountain forest region, Cameroon. FAO working paper, Rome, 42 pp. Conservation and sustainable management.

Deb, S., Arunachalam, A. and Das, A. K. (2009). Indigenous knowledge of Nyishi tribes' on Traditional Agroforestry Systems. Indian Journal on Traditional Knowledge, 8 (1), 41 - 46.

EL - Lankany, H. (2004). Improvement for rural livelihoods: World Agroforestry Conference, 27 June - 2 July, Orlando, Florida, USA, Pp1-4.

Eze, B.E. \& Ndenecho, E.N. (2006) A conceptual framework for ecological and socially sustainable land management and agricultural development in Africa. International Journal of Environment and Sustainable Development. (5) Pp.275 285.

FAO. (2010). Addressing food security in protracted crises. Food and Agriculture Organization of the United Nations.

Foncha, J.N. (2012). An evaluation of the success of participatory forest management in the Mount Oku Forest Region, 
Cameroon. (An Unpublished PhD Thesis Pp. 89 - 100).

Furon, R. (1963). Geology of Africa. Edinburg: Oliver and Boyd.

Gardner, A., De Marco, J. \& Asanga, C. (2001). A conservation partnership: Community forestry at Kilum-Ijim. Rome: Rural Development Forestry Network.

ICRAF- West and Central Africa (WCA). (2007). Growing Out of Poverty. Trees cultivation in West and -Central Africa for home and markets, grants, T.A. No. 697- ICRAF, funded by International Fund for Agricultural Development, Project Completion Report 2004 - 2007 PP 5 - 9.

ICRAF-WCA. (2009). Improving livelihood through agroforestry. World Agroforestry Centre. Yaoundé Cameroon, $37 \mathrm{pp}$.

Islam, M.A., Qaisar, K.N. and Bhat, G.M. (2017). Indigenous knowledge in traditional agroforestry systems of Kashmir Valley: Current challenges and future opportunities. International Journal of forestry and crop improvement, 8 (1) pp 66 -77 .

Jose, S. (2009). Agroforestry for ecosystem services and environmental benefits: an overview, Agroforestry Systems, 76: $1-10$.

Lungdream, B. and Raintree, J.B. (1983). Sustained Agroforestry, Agril. Research for Development potential and Challenges in Asia. The Hague ISNAR, Pp 1 - 25

Ndenecho, E. N. (2009). Cropping systems and post cultivation succession, agro - ecosystem in Ndop Cameroon. Journal of Human Ecology, 27, (1) 26 -30.

Neba, A. S. (1982). Modern geography of the United Republic of Cameroon. New York: Hamilton Printing Company.

Negash, M., and Acholo, M. (2008). History of indigenous agroforestry in Gedeo, South Ehiopia, based on local community Interview: Vegetation Diversity and Structure in the Land use Systems. Ethiopia Journal of Natural Resources. $10(1) 31-52$.

Numbem, S. T. (1985). The conservation of Oku mountain forest, Cameroon. Cambridge:

Owonubi, J.J. (2002). Disappearing Forests: A review of the challenges for conservation of genetic resources and environmental management. Journal of Forest Resource Management. 2 (1) 11-20.

Pratrap, T., Rakesh, K., Lalit, T. and Anand, S. (2017). Agroforestry for sustainable rural livelihoods. International Journal of Pure and Applied Bioscience. 5 (1) 299 -309.

Quanddt, A., Neufeidt, H. and McCable, J.T. (2017). The role of agroforestry in building livehood resilience to flood and drought in semi - Arid Kenya. Ecology and Society 22 (3) 10 - 14.

Rao, Y. S. and MacDicken, K.G (1991). Foreward In: agroforestry Asia and the Pacific, Mellick, W. Rao, Y.S and MacDicken, K.G. (eds) RAPA Publications $1-2$.

Sinhai, B.N. (1985). The Role of Agroforestry in soil and Water Conservation, in: (Muhammed, S. eds.), Proceedings in Social Forestry workshop B.A U, 90-99.

Thomas, O., Gardner, A. \& Demario, J. (2001). Devolution of decision-making: Lessons from community forest management at Kilum-Ijim forest project, Cameroon. Jeffery, R. \& Vira, B. (Eds.), Conflict and cooperation in participating natural resource management. Guatemala: Global Issues Series International Council for Bird Preservation.

Torres, F. (1985), Network of Generation of Agroforestry Technology in Africa, ICRAF, Workshop Paper No. 31, Nairobi, September 1982, ICRAF, Nairobi, PP 1- 25.

World Agroforestry (2008). Improving livelihoods through agroforestry. Annual Report 2008 1-14.

World Bank (2005). 'Unlocking opportunities for forest dependent people in India'. Sector Report no. 34481, World Bank, Washington D. 